Abstracta Iranica Abstracta Iranica

Revue bibliographique pour le domaine irano-aryen

Volume 23 | 2002

Comptes rendus des publications de $\mathbf{2 0 0 0}$

\title{
« Vāže-sāzī-e darūn-matn, yek 'elāj-e qaț'ī ». Našr-e Dāneš, 17, 1 (1379/2000), pp. 27-31.
}

\section{Charles-Henri de Fouchécour}

\section{(2) OpenEdition}

1 Journals

\section{Édition électronique}

URL : http://journals.openedition.org/abstractairanica/35165

DOI : 10.4000/abstractairanica.35165

ISSN : 1961-960X

Éditeur :

CNRS (UMR 7528 Mondes iraniens et indiens), Éditions de l'IFRI

\section{Édition imprimée}

Date de publication : 15 mai 2002

ISSN : 0240-8910

\section{Référence électronique}

Charles-Henri de Fouchécour, « « Vāže-sāzī-e darūn-matn, yek 'elāj-e qaț̌i ». Našr-e Dāneš, 17, 1

(1379/2000), pp. 27-31. », Abstracta Iranica [En ligne], Volume 23 | 2002, document 33, mis en ligne le 08 février 2010, consulté le 25 septembre 2020. URL : http://journals.openedition.org/ abstractairanica/35165 ; DOI : https://doi.org/10.4000/abstractairanica.35165

Ce document a été généré automatiquement le 25 septembre 2020.

Tous droits réservés 


\title{
«Vāže-sāzì-e darūn-matn, yek 'elāj- e qaț ${ }^{\prime} \overline{1}$ ». Našr-e Dāneš, 17, 1 (1379/2000), pp. 27-31.
}

\author{
Charles-Henri de Fouchécour
}

1 Immense est le problème des mots nouveaux nécessaires à l'expression des besoins nouveaux de notre temps. L'auteur examine les quatre voies possibles: 1) l'emprunt (vām-gīì $)$, direct ou par l'intermédiaire d'une autre langue, comme le turc, ou par adaptation nouvelle d'un mot ancien de la langue empruntée, ou par emprunt d'un mot déjà adapté par une langue sœur;2) l'extension de sens d'un mot existant ; 3) la construction grammaticale correcte (v.gr. jacbe-ye āvāz, grammophone); 4) la dérivation, comme razmāyeš, manœuvre. Il est clair que seules conviennent les deux dernières manières : composition grammaticale (tarkib-e nahvī) et construction de mot (vāže-sāzi $)$, i.e. usage de mots et d'éléments lexicaux déjà existants dans la langue emprunteuse. L'extension de sens (basț-e ma $\left.a^{\prime} n \bar{a} \bar{\imath}\right)$ est source de confusion et peut contredire la grammaire ; ce n'est pas un véritable enrichissement de la langue. Seule la dérivation est capable de produire de vrais mots qui auront longue vie. Il faut encore distinguer la confection de mots faite arbitrairement, hors contexte (vāže-sāzīe borūnmatn), par des spécialistes d'un domaine, par des traducteurs, etc., comme bād-roft (érosion éolienne). Elle est bien "persane", c'est une sorte de palier de raffinage (pālāyeš). Mais seuls les mots nouveaux créés en contexte (darūn-matn) seront les plus vite acceptés et répandus. Ceci suppose que les créateurs soient exercés à la dérivation (șarf-e ešteqāq), qu'ils aient le sens de la langue et de ses rythmes, de sorte qu'ils perçoivent ce qui conviendra à l'usage courant de tous. 
INDEX

Thèmes : 2.2. Langues vivantes et dialectes

\section{AUTEURS}

CHARLES-HENRI DE FOUCHÉCOUR

Sorbonne Nouvelle - Paris III 